\title{
Variation in Nitrogen Rate and Local Availability Alter Root Architecture Attributes at the Onset of Storage Root Initiation in 'Beauregard' Sweetpotato
}

\author{
Arthur Villordon ${ }^{1}$ \\ LSU AgCenter Sweet Potato Research Station, 130 Sweet Potato Road, \\ Chase, LA 71324
}

\author{
Don LaBonte \\ LSU AgCenter School of Plant, Environmental, and Soil Sciences, 137 J.C. \\ Miller Hall, Baton Rouge, LA 70803-2120
}

\author{
Nurit Firon \\ Institute of Plant Sciences, The Volcani Center, Agricultural Research \\ Organization, P.O. Box 6, Bet Dagan, 50250, Israel
}

\section{Edward Carey \\ International Potato Center (CIP), c/o CSIR-CRI, P.O. Box 3875, Kumasi, Ghana}

Additional index words. Ipomoea batatas, nitrogen use efficiency, split-root culture system, lateral roots

\begin{abstract}
This study characterized the influence of nitrogen $(\mathrm{N})$ rates and variation in local availability on root architecture as measured by lateral root (LR) development attributes during the onset of the storage root (SR) initiation stage in 'Beauregard' sweetpotato adventitious roots (ARs). In $N$ rate experiments, plants grown without fertilizer $\mathbf{N}$ showed significantly lower values for all measured $L R$ attributes compared with fertilized plants. Total first- (1LR) and second-order LR (2LR) length increased by $78 \%$ and $2873 \%$, respectively, as $\mathrm{N}$ was increased from 0 to $50 \mathrm{~kg} \cdot \mathrm{ha}^{-1}$. Total $1 \mathrm{LR}$ and 2LR number increased by $32 \%$ and $1465 \%$, respectively. Increasing the $N$ rates to 100 and $200 \mathrm{~kg} \cdot \mathrm{ha}^{-1}$ did not result in further increases for all LR attributes measured. There were no differences in AR number between untreated controls and plants fertilized with $50 \mathrm{~kg} N / \mathrm{ha}$. However, the number of ARs increased by $65 \%$ when fertilizer $\mathrm{N}$ was increased from 50 to $100 \mathrm{~kg} \cdot \mathrm{ha}^{-1}$. Increasing the rate to $200 \mathrm{~kg} \cdot \mathrm{ha}^{-1}$ did not result in further increases in $A R$ number. In split-root experiments, roots grown in the compartment with $50 \mathrm{~kg} \mathrm{~N} / \mathrm{ha}$ had $135 \%$ and $2916 \%$ increase in total $1 \mathrm{LR}$ and $2 \mathrm{LR}$ length, respectively, compared with roots grown in the compartment without fertilizer $\mathbf{N}$. Total $1 L R$ and 2 LR number increased by $110 \%$ and $2114 \%$, respectively. There were $111 \%$ more ARs in the fertilized compartment relative to the unfertilized compartment. There were no differences in $L R$ attributes and AR number between compartments that received similar fertilizer $N$ rates. In fertilizer placement experiments, there were no differences in LR attributes between pre-mixing fertilizer $N$ and placement of fertilizer $\approx 4 \mathrm{~cm}$ below the surface of the growth substrate. There were also no differences between the unfertilized control and placement of fertilizer $\approx 4 \mathrm{~cm}$ from the bottom of the pot. Plants grown in substrate with pre-mixed $N$ showed $38 \%$ and $342 \%$ increase in 1LR and 2LR length, respectively, relative to the bottom placement of $N$. Total number of $1 \mathrm{LR}$ and 2LR in the growth substrate with pre-mixed $N$ increased by $30 \%$ and $312 \%$, respectively, relative to the bottom placement of $N$. These results represent the first evidence for the association between sweetpotato root architectural attributes and variation in $\mathrm{N}$ rate and localized availability. These results are also consistent with findings in model systems in which local $N$ presence is necessary for $L R$ development. This information can be used to further optimize SR yield by helping to ensure the availability of $N$ at the optimum rate across time and space.
\end{abstract}

Root system architecture has been referred to as an integrative result of LR initiation, morphogenesis, emergence, and growth (Dubrovsky and Forde, 2012). LRs contribute to water use efficiency and facilitate the extraction of micro- and macronutrients from the soil (Casimiro et al., 2003).
Our current understanding of the regulation of root architecture is based on a subset of well-characterized "model" species including major global food crops such as wheat, rice, and maize. In sweetpotatoes, an important global food crop, an understanding of factors that influence LR development is important because LR attributes like length and density are associated with the onset of anatomical cues of SR formation, which are detectable within $20 \mathrm{~d}$ after transplanting in 'Beauregard' ARs (Villordon et al., 2009a, 2012). This knowledge can be used to develop practical management tools to further improve production efficiency. SR initiation has previously been defined as the appearance of cambia around the protoxylem and secondary xylem elements (Togari, 1950; Wilson and Lowe, 1973). It has been shown in model systems that external and internal variables directly influence LR development. Internal cues of LR formation include auxin, ethylene, abscisic acid, and cytokinin (De Smet et al., 2003; Ivanchenko et al., 2008; Lopez-Bucio et al., 2002). External variables include soil nutrients such as ammonium $\left(\mathrm{NH}_{4}{ }^{+}\right)$(Lima et al., 2010), nitrate $\left(\mathrm{NO}_{3}{ }^{-}\right)$ (Zhang and Forde, 1998), phosphate (Johnson et al., 1996), and sulfate (Kutz et al., 2002). Of particular interest is $\mathrm{N}$ because it has been documented that local and systemic signaling pathways exist for plant $\mathrm{N}$ responses (Alvarez et al., 2012). Knowledge about possible local effects is very important because this can lead directly to the development and testing of management practices that optimize root architecture development and improve nutrient use efficiency. The primary objective of this work was to investigate the effect of variability in $\mathrm{N}$ rate and local availability on root architecture characteristics as measured by LR development attributes in 'Beauregard' sweetpotato. The majority of studies on the nutritional effects on root architecture in model systems has been conducted either in solution or in a growth substrate supplied with nutrient solution. An overarching goal of this work was to closely mimic natural conditions by using a growth substrate supplied with fertilizer granules within the context of a greenhouse culture system in which the timing of LR development and SR formation events has been validated by field data (Villordon et al., 2009a, 2009b, 2011, 2012).

\section{Materials and Methods}

Plant materials. The greenhouse experiments were conducted in Chase, LA (lat. $32^{\circ} 6^{\prime}$ $\mathrm{N}$, long. $91^{\circ} 42^{\prime} \mathrm{W}$ ). On 25 Oct. 2012, virustested 'Beauregard' Generation 1 (G1) SRs bedded in washed river sand served as a source of cuttings for all experiments. The equivalent of $17 \mathrm{~kg} \mathrm{~N} / \mathrm{ha}$ and $60 \mathrm{~kg} \cdot \mathrm{ha}^{-1}$ each of $\mathrm{P}_{2} \mathrm{O}_{5}$ and $\mathrm{K}_{2} \mathrm{O}$ was applied to the growth substrate used for producing the cuttings. After each cutting, a half rate of each nutrient was applied. The first set of experiments (N RATE) used different rates of $\mathrm{N}$ in the form of granular urea (46-0-0), equivalent to 0 , 50,100 , and $200 \mathrm{~kg} \mathrm{~N} / \mathrm{ha}$. In Louisiana, sweetpotato growers commonly use urea or urea-containing fertilizers (Cannon, personal communication). The $\mathrm{N}$ rate of $50 \mathrm{~kg} \cdot \mathrm{ha}^{-1}$ has been documented by previous work as optimum for 'Beauregard' in Louisiana (Mulkey et al., 1994). The second set of experiments used a split-root culture system (SPLIT ROOT) 
(Fig. 1). ARs from one plant were exposed to two contrasting $\mathrm{N}$ rates, i.e., 0 and $50 \mathrm{~kg} \cdot \mathrm{ha}^{-1}$ (0N:50N). Pots with $0 \mathrm{~N}: 0 \mathrm{~N}$ (no supplemental $\mathrm{N}$ ) and $50 \mathrm{~N}: 50 \mathrm{~N}$ (the equivalent of $50 \mathrm{~kg} \cdot \mathrm{ha}^{-1}$ was applied in each compartment) fertilizer $\mathrm{N}$ treatments were used as controls. The third set of experiments (N PLACEMENT) used one $\mathrm{N}$ rate $\left(50 \mathrm{~kg} \cdot \mathrm{ha}^{-1}\right)$ but varied the horizontal placement of the fertilizer N. In the first treatment, fertilizer $\mathrm{N}$ was premixed with the growth substrate before filling the pots (MIX N). The other treatments consisted of placing fertilizer $\mathrm{N} 4 \mathrm{~cm}$ from the surface (TOP N) or the bottom (BOTTOM N) of the pot. Pots that did not receive $\mathrm{N}$ were designated as control treatments (CONTROL). In all experiments, the rate of each of $\mathrm{P}_{2} \mathrm{O}_{5}$ and $\mathrm{K}_{2} \mathrm{O}$ was equivalent to $134 \mathrm{~kg} \cdot \mathrm{ha}^{-1}$. Phosphorus was provided as $0-46-0$, whereas potassium was provided as $0-0-62$. Washed river sand was used as a growth substrate for all experiments. The diameter of sand particles varied from 0.05 to $0.9 \mathrm{~mm}$ with the majority $(83 \%)$ in the $0.2-$ to $0.9-\mathrm{mm}$ range. Growth substrate samples submitted to A\&L Analytical Laboratories (Memphis, TN) showed no detectable $\mathrm{NO}_{3}{ }^{-}, \mathrm{NH}_{4}{ }^{+}$, or organic matter. Unless otherwise specified, all fertilizer materials were thoroughly mixed with the growth substrate before filling the pots. In the N RATE and N PLACEMENT experiments, cuttings were set in 10 -cm-diameter polyvinyl chloride $(\mathrm{PVC})$ pots (height $=30 \mathrm{~cm}$ ) with detachable plastic bottoms. Each plastic bottom had five drain holes $(2 \mathrm{~mm}$ in diameter). In addition, each PVC pot had four rows of side drain holes $(2 \mathrm{~mm}$ in diameter; $3 \mathrm{~cm}$ apart within row) that were located diametrically opposite each other. Similar materials were used for the SPLIT ROOT experiments except that an acrylic strip $(0.6 \mathrm{~cm}$ thick) was inserted into each PVC pot to create two compartments (Fig. 1-I). The acrylic strip was secured with PVC glue to minimize lateral movement of water. A notch on the top end of the acrylic strip allowed a cutting to be set such that AR primordia on either side of the basal leaf gap or node were directed toward separate compartments

Received for publication 4 Mar. 2013. Accepted for publication 8 Apr. 2013.

Portions of this research were supported by $\mathrm{Re}-$ search Grant No. US-4015-07 from BARD, the U.S.-Israel Binational Agricultural Research and Development, USDA NIFA SCRI 2009-5118106071, and the Louisiana Sweetpotato Advertising and Development Fund.

We thank Drs. Brenda Tubana, Pedro Lloret, and Stan Kays for their comments on an earlier version of the manuscript.

Mention of trademark, proprietary product or method, and vendor does not imply endorsement by the Louisiana State University Agricultural Center nor its approval to the exclusion of other suitable products or vendors.

Approved for publication by the Director of the Louisiana Agricultural Experiment Station as manuscript number 2013-260-7872.

${ }^{1}$ To whom reprint requests should be addressed; e-mail avillordon@agcenter.lsu.edu.
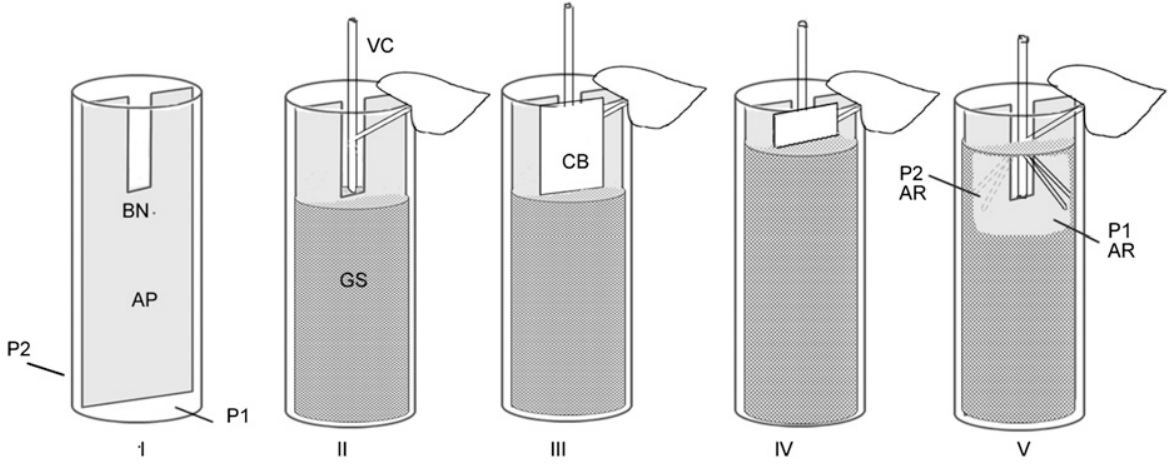

Fig. 1. Materials and methods used in the split-root culture system. A notched acrylic partition (AP) was inserted into a polyvinyl chloride pot to create two partitions (P1 and P2) and glued in place (I). Growth substrate (GS) with pre-mixed fertilizer treatment was poured into each partition, initially to the bottom of the notch (BN) (II). The planting material (VC) was set and positioned such that adventitious root (AR) primordia were directed into opposing partitions. A piece of cardboard (CB) was then inserted (III), and additional GS was added to cover two to three nodes (IV). After adding sufficient GS, the CB was carefully removed (V).

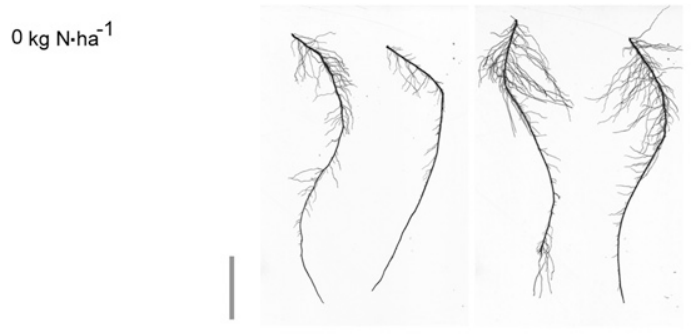

$50 \mathrm{~kg} \mathrm{~N} \cdot \mathrm{ha} \mathrm{a}^{-1}$
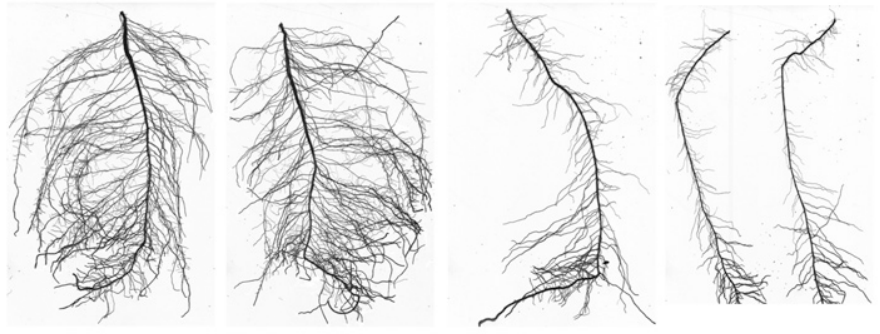

$100 \mathrm{~kg} \mathrm{~N} \cdot \mathrm{ha}^{-1}$
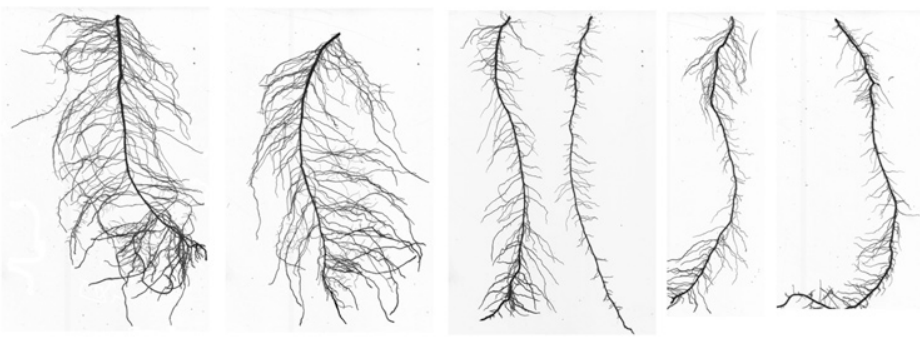

$200 \mathrm{~kg} \mathrm{~N} \cdot \mathrm{ha}^{-1}$
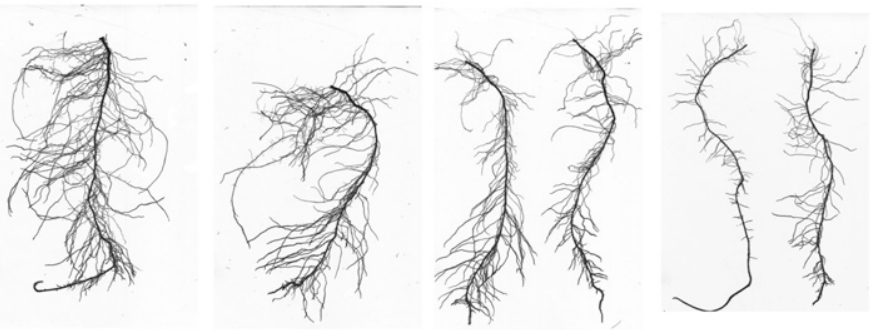

Fig. 2. Adventitious root samples from plants subjected to $0,50,100$, and $200 \mathrm{~kg}$ nitrogen $(\mathrm{N}) / \mathrm{ha}$. These images were obtained from a complete replicate in the first N RATE experiment. Scale bar $=5 \mathrm{~cm}$.

(Fig. 1-II). ARs from other nodes were forced to grow in either compartment. The greenhouse temperature regime was $29^{\circ} \mathrm{C}$ for $14 \mathrm{~h}$ (day) and $18{ }^{\circ} \mathrm{C}$ for $10 \mathrm{~h}$ (night). Photosynthetic photon flux $(P P F)$ for all experiments ranged from 400 to $1300 \mu \mathrm{mol} \cdot \mathrm{m}^{-2} \cdot \mathrm{s}^{-1}$. Supplementary lighting was provided using lightemitting diode grow lights (Lumigrow, Novato, CA) for $14 \mathrm{~h}$ per day. $P P F$ was measured at the canopy level with a quantum sensor 
(Model QSO-S; Decagon Devices Inc., Pullman, WA). The relative humidity (RH) averaged $60 \%$. Temperature and $\mathrm{RH}$ were monitored at the canopy level using an integrated temperature and $\mathrm{RH}$ sensor (Model RHT; Decagon Devices Inc.). Unless otherwise indicated, the moisture of the growth substrate was maintained $\approx 50 \%$ of field capacity (FC) $[\approx 7 \%$ volumetric water content (VWC)]. Growth substrate moisture was measured with $\mathrm{ECH}_{2} \mathrm{O}$ soil moisture sensors (Model EC-5; Decagon Devices Inc.) inserted vertically at the $2-$ to $7-\mathrm{cm}$ depth. These growth conditions were very similar to those used in previous experiments that characterized AR development and the timing of SR initiation in 'Beauregard' sweetpotato (Villordon et al., 2009a, 2009b). Distilled water was used in all experiments and applied manually with a measuring cup to help ensure uniformity of substrate moisture.

The planting dates for the $\mathrm{N}$ rate experiments were 7 Nov. 2012 and 30 Nov. 2012.
The planting dates for the split-root experiments were 12 Dec. 2012 and 7 Jan. 2013. The planting dates for the $\mathrm{N}$ placement experiments were 23 Dec. 2012 and 31 Dec. 2012. In all experiments, plants were grown for $20 \mathrm{~d}$ after which near-intact root systems were collected. At harvest, the detachable plastic bottoms were removed and the pot was tilted and the growth substrate was gradually removed using a stream of water. A composite leaf sample for each treatment of the N RATE test was submitted to LSU AgCenter Soil Testing and Plant Analysis Laboratory to generate preliminary leaf tissue analysis data. A composite sample for each treatment of the N PLACEMENT test was sent to A\&L Analytical Laboratories for similar analyses. A separate experiment was conducted to determine the $\mathrm{NO}_{3}{ }^{-}$and $\mathrm{NH}_{4}{ }^{+}$ content of the growth substrate at $5,10,15$, and $20 \mathrm{~d}$ under two $\mathrm{N}$ rates $\left(0\right.$ and $\left.50 \mathrm{~kg} \cdot \mathrm{ha}^{-1}\right)$. Samples of the growth substrate were sent to A\&L Analytical Laboratories for $\mathrm{NO}_{3}^{-}$and
$\mathrm{NH}_{4}{ }^{+}$analyses. Root architecture data were also obtained for each sampling period. All experiments were arranged as a randomized complete block repeated across planting dates. There were four replicates (one plant per pot $=$ one replicate) per experimental treatment in each of the experiments.

Root image acquisition and analysis. In all experiments, intact ARs that were $15 \mathrm{~cm}$ or greater in length were floated on waterproof trays and scanned using a specialized Dual Scan optical scanner (Regent Instruments Inc., Quebec, Canada). Based on previous studies in 'Beauregard,' ARs $15 \mathrm{~cm}$ or less in length failed to show the anatomical attributes associated with lignification or SR initiation at $20 \mathrm{~d}$ (Villordon et al., 2009a, 2012). Image acquisition parameter was set to "high" accuracy (600 dpi; image size $\approx 18$ $\mathrm{MB})$, whereas analysis precision was set to "high." The acquisition and image analysis software was WinRHIZO Pro (Version 2009c; Regent Instruments Inc.). Debris removal
Total second order lateral root length

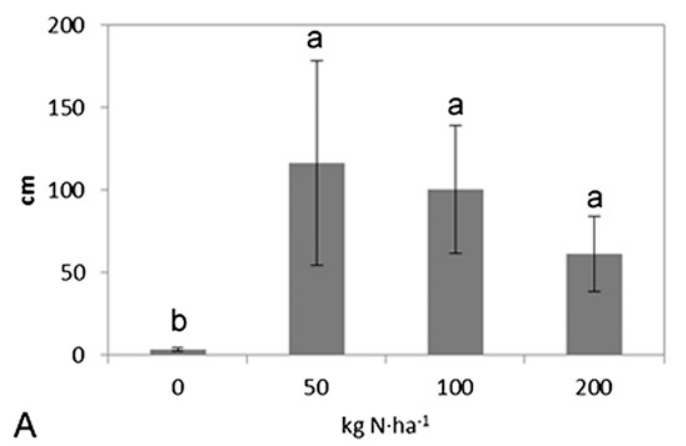

Total number of second order lateral roots

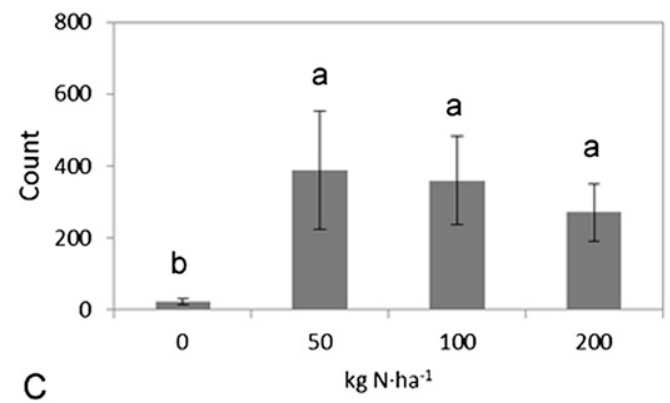

Second order lateral root density

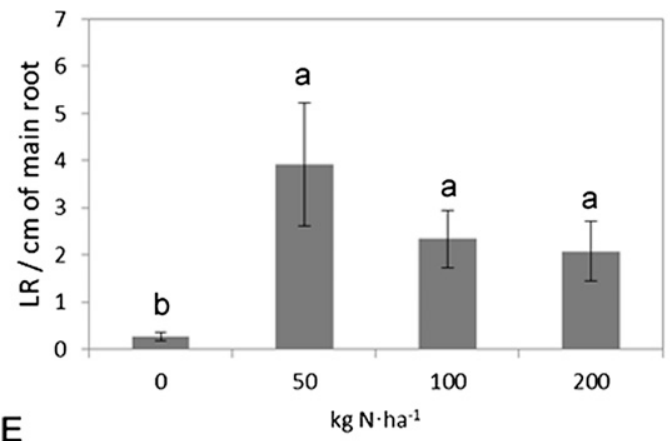

Total first order lateral root length

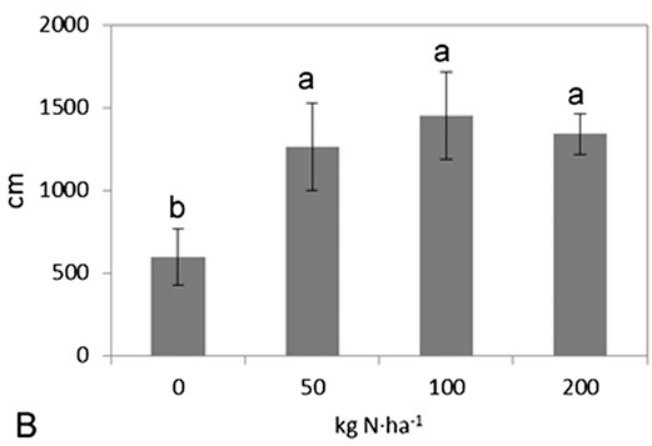

Total number of first order lateral roots

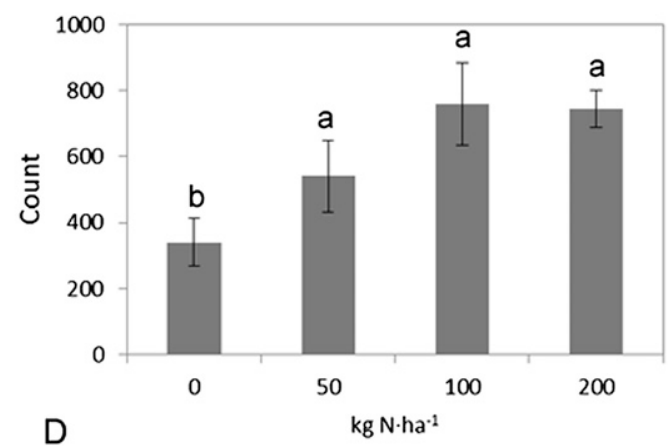

First order lateral root density

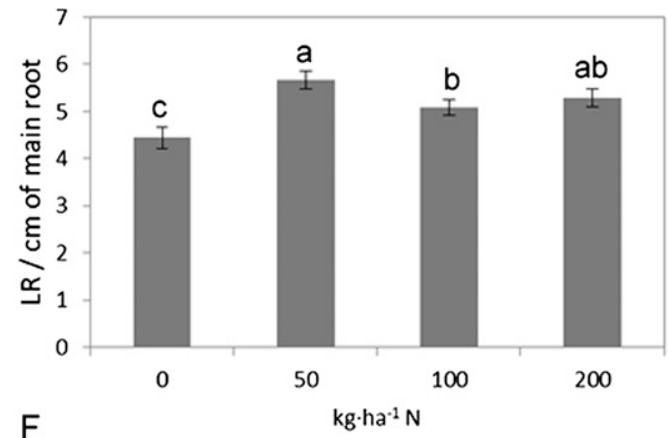

Fig. 3. Some statistical descriptive data of lateral root attributes of 'Beauregard' sweetpotato subjected to different nitrogen (N) rates. Columns with different letters differ significantly at the $5 \%$ level by Fisher's least significant difference. 
among scanned images was performed manually using the WinRhizo Pro Edition working mode. Debris consisted mainly of images of sand particles and occasional broken root segments ( $1 \mathrm{~cm}$ or less in length). Root types were automatically classified based on root diameter, which was in turn based on predetermined size intervals. In the present work, three intervals were used: 0 to $0.2,0.2$ to 1.0 , and 1.0 to $20 \mathrm{~mm}$. These intervals were used to classify 2LR, 1LR, and the main AR, respectively. These intervals were dynamically adjusted between samples because the diameter of $1 \mathrm{LR}$ varied from sample to sample and sometimes overlapped with 2LRs, if present. Wilson and Lowe (1973) have previously reported that around the onset of SR initiation, the main ARs were "approximately" $1 \mathrm{~mm}$. LR attributes that were measured from scanned images included LR count (total count of 1LR and 2LR) and LR length (total length of 1LR and 2LR). The length of the main $\operatorname{root}(\mathrm{MR})$ was verified using ImageTool (Univ. of Texas Health Science Center at San Antonio, available from $<\mathrm{ftp}: / /$ maxrad6.uthscsa.edu $>$ ). 1LR and 2LR density was calculated by dividing $1 \mathrm{LR}$ and 2LR count, respectively, by MR length.

Data collection and statistical analysis. LR attribute data from each experiment were pooled after verifying the lack of date effects. AR length and count data were transformed using $\log 10$ and square root transformation, respectively. Statistical analyses on the $\mathrm{N}$ RATE and N PLACEMENT experiments were performed using SAS Proc Mixed (SAS Version 9.1; SAS Inc., Cary, NC). Fisher's least significant difference test at the $0.05 P$ level was used to test for statistical significance. The data presented were means and SEM from non-transformed data. Data from the SPLIT ROOT experiments were analyzed using SAS PROC TTEST using the PAIRED statement (SAS Version 9.1; SAS Inc.).

\section{Results}

Nitrogen rate experiments. Representative images from each of the N RATE treatments are shown in Figure 2. Total 2LR and 1LR length increased by $2873 \%$ and $78 \%$ among plants that received $50 \mathrm{~kg} \mathrm{~N} /$ ha relative to the control treatment (no supplemental $\mathrm{N}$ ) (Fig. 3). 2LR and 1LR number increased by $1465 \%$ and $32 \%$, respectively. 2LR and $1 L R$ density increased by $1368 \%$ and $27 \%$, respectively. Increasing the $\mathrm{N}$ rates to 100 and $200 \mathrm{~kg} \cdot \mathrm{ha}^{-1}$ did not result in further increases for all LR attributes measured. There were no differences in AR number between untreated controls and plants fertilized with 50 $\mathrm{kg} \mathrm{N} /$ ha (Fig. 4A). However, the number of ARs increased by $65 \%$ when fertilizer $\mathrm{N}$ was increased from 50 to $100 \mathrm{~kg} \cdot \mathrm{ha}^{-1}$ (Fig. 4A) Increasing the rate to $200 \mathrm{~kg} \cdot \mathrm{ha}^{-1}$ did not result in a further increase in AR number.

Split-root experiments. Representative images of AR samples from each of the experimental treatments are shown in Figure 5. 2LR and $1 L R$ length increased by $2916 \%$ and $135 \%$, respectively, among roots that were grown in

\section{Number of adventitious roots}

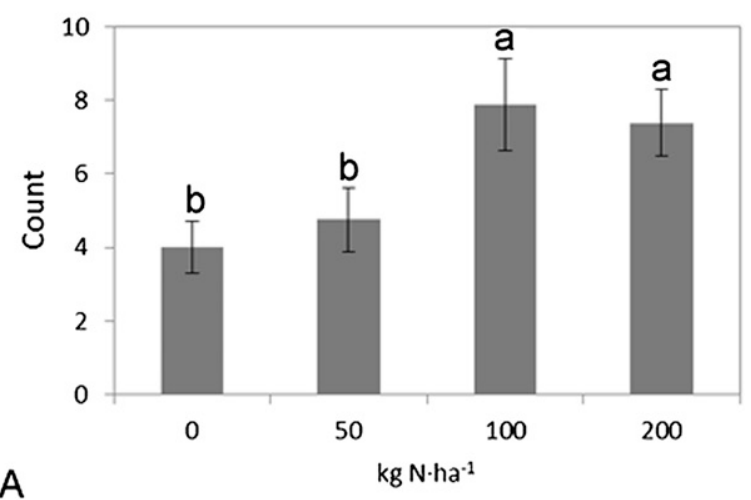

Number of adventitious roots

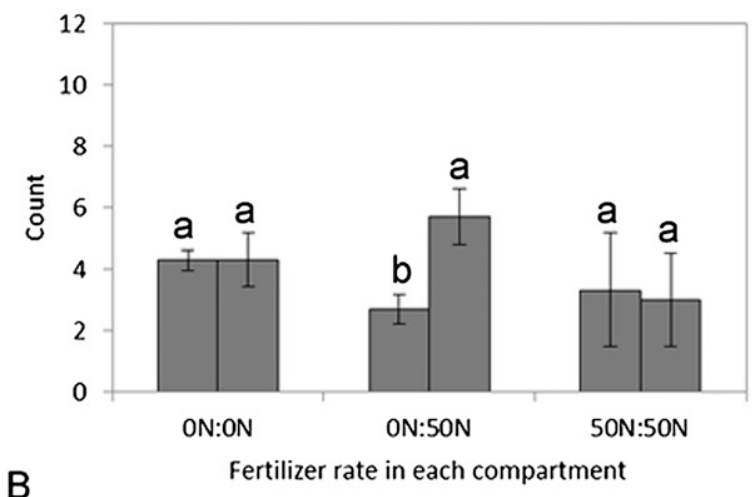

Number of adventitious roots

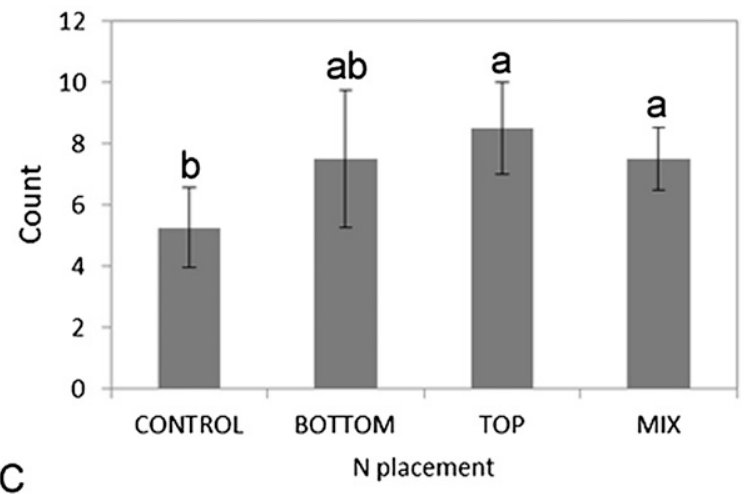

Fig. 4. Adventitious root number in 'Beauregard' sweetpotato as influenced by nitrogen $(\mathrm{N})$ rate (A), splitroot treatments $(\mathbf{B})$, and fertilizer $\mathrm{N}$ placement $(\mathbf{C})$. For 7A and 7C, columns with different letters differ significantly at the $5 \%$ level by Fisher's least significant difference. For $7 \mathrm{~B}$, paired columns with different letters differ significantly at the $5 \%$ level by Fisher's least significant difference. For split-root experiments: $50 \mathrm{~N}=50 \mathrm{~kg} \cdot \mathrm{ha}^{-1} \mathrm{~N} ; 0 \mathrm{~N}=$ unfertilized control. For fertilizer $\mathrm{N}$ treatments: $\mathrm{CONTROL}=$ no fertilizer $\mathrm{N}$ added; BOTTOM $=$ fertilizer $\mathrm{N}$ placed $4 \mathrm{~cm}$ from the bottom of the pot; $\mathrm{MIX}=$ fertilizer $\mathrm{N}$ was pre-mixed with growth substrate; TOP $=$ fertilizer $\mathrm{N}$ was placed $4 \mathrm{~cm}$ from the surface of the growth substrate.

the compartment that received $50 \mathrm{~kg} \mathrm{~N} / \mathrm{ha}$ relative to roots that were grown in the compartment without supplemental N (Fig. 6). 2LR and 1LR number increased by $2114 \%$ and $110 \%$, respectively. 2LR density increased by $1100 \%$. There were $111 \%$ more AR in the compartment that received $50 \mathrm{~kg} \mathrm{~N} / \mathrm{ha}$ relative to the compartment that did not receive fertilizer $\mathrm{N}$ (Fig. 4B). There were no differences in LR attributes and AR number between compartments without fertilizer or with similar rates of $\mathrm{N}\left(50 \mathrm{~kg} \cdot \mathrm{ha}^{-1}\right)$.
Nitrogen placement experiments. There were no differences in LR development response between MIX N and TOP N (Fig. 7). There were also no differences between the control treatment and BOTTOM N. Plants grown in MIX $\mathrm{N}$ showed $342 \%$ and $38 \%$ increase in $2 \mathrm{LR}$ and $1 \mathrm{LR}$ length, respectively, relative to BOTTOM N. Total number of $2 \mathrm{LR}$ and 1LR in MIX $\mathrm{N}$ increased by $312 \%$ and $30 \%$, respectively, relative to BOTTOM N. 2LR and 1LRdensity increased by $407 \%$ and $34 \%$, respectively. There were 


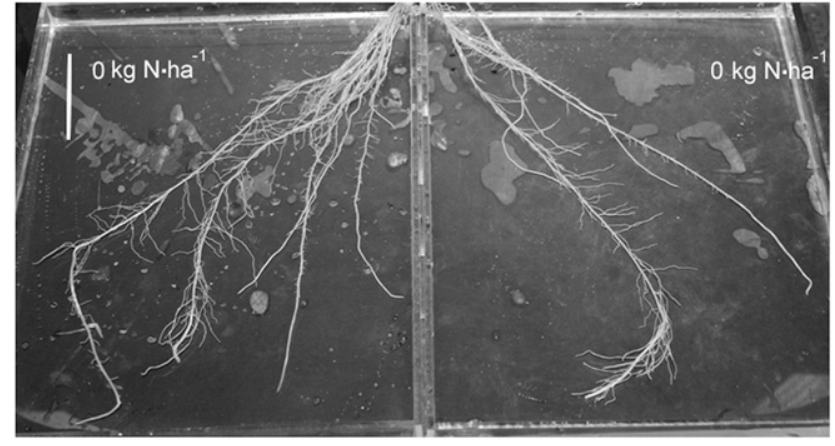

A

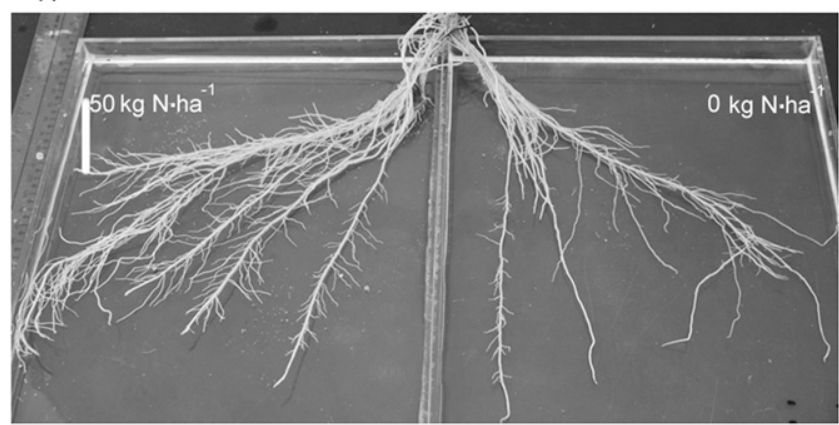

B

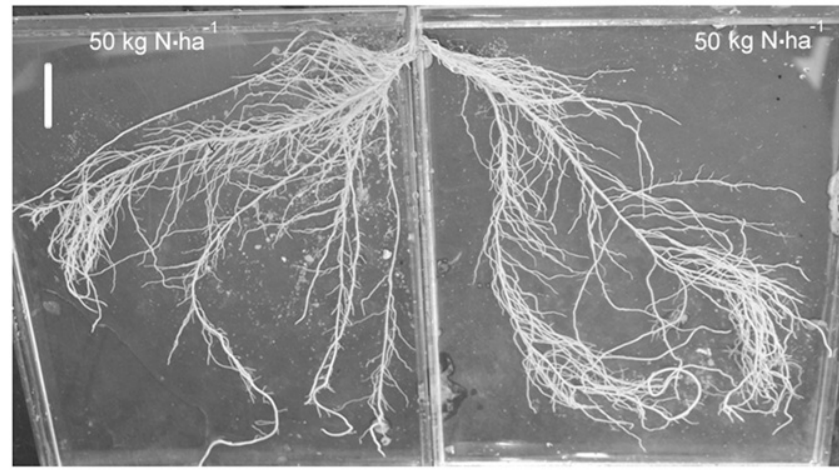

C

Fig. 5. Representative adventitious root samples from split-root experiments. The adventitious roots that were still attached to the plant were floated on waterproof trays to facilitate image capture. Corresponding nitrogen $(\mathrm{N})$ rates for each partition are indicated for each tray. Scale bar $=5 \mathrm{~cm}$.

$34 \%$ more AR in MIX N plants relative to the BOTTOM N plants.

\section{Discussion}

We have previously provided evidence that variation in growth substrate moisture altered 'Beauregard' sweetpotato AR architectural attributes at the onset of SR initiation (Villordon et al., 2012). In the current study, the results show that even with optimum substrate moisture, variation in $\mathrm{N}$ rate and local availability can significantly alter root architecture attributes at the onset of SR initiation. In the N RATE experiments, plants grown in growth substrate without supplemental $\mathrm{N}$ consistently showed reduced LR development, which was previously demonstrated to be associated with diminished probability for SR formation (Villordon et al., 2012). Increasing the $\mathrm{N}$ rate from 0 to the equivalent of $50 \mathrm{~kg} \cdot \mathrm{ha}^{-1}$ reversed these negative effects. There were slight increases in measurable LR attributes when $\mathrm{N}$ rate was doubled to $100 \mathrm{~kg} \cdot \mathrm{ha}^{-1}$. Further doubling the rate to $200 \mathrm{~kg} \mathrm{~N} / \mathrm{ha}$ resulted in slight gains or reductions. These results are consistent with findings in model systems that $\mathrm{N}$ presence has a stimulatory effect on LR growth, whereas high $\mathrm{N}$ concentrations are inhibitory (Zhang et al., 2007). These opposing responses to the same nutrient reflect a sophisticated mechanism whereby plants calibrate response to $\mathrm{N}$ supply and respond precisely to its abundance (Zhang et al., 2007). The results from our work coincide with field plot data regarding $\mathrm{N}$ rate effects on SR yield in 'Beauregard,' particularly in the southeastern U.S. production regions. Mulkey at al. (1994) reported that the maximum yield of 'Beauregard' U.S. No. 1 grade roots was obtained using $50 \mathrm{~kg} \cdot \mathrm{ha}^{-1}$ in Louisiana. Phillips et al. (2005) reported that optimum $\mathrm{N}$ rates for 'Beauregard' grown in Virginia varied from 28 to $56 \mathrm{~kg} \cdot \mathrm{ha}^{-1}$ for production environments associated with normal and above-average precipitation, respectively. Very often, $\mathrm{N}$ rate treatments failed to show statistical differences. For example,
Schultheis et al. (1995) reported the lack of yield differences in 'Beauregard' that was subjected to $\mathrm{N}$ rates ranging from 14 to 56 $\mathrm{kg} \cdot \mathrm{ha}^{-1}$ in North Carolina. However, they observed a significant yield increase between the unfertilized checks and all fertilized plots. Guertal and Kemble (1997) reported the lack of yield differences in 'Beauregard' with $\mathrm{N}$ rates of $0,36,72$, and $108 \mathrm{~kg} \cdot \mathrm{ha}^{-1}$ in Alabama. Previous work on other cultivars has also documented the lack of response of added $\mathrm{N}$ of $60 \mathrm{~kg} \cdot \mathrm{ha}^{-1}$ (Hill et al., 1988). The data from field experiments and the lack of significant increases in LR development attributes associated with $\mathrm{N}$ rates greater than $50 \mathrm{~kg} \cdot \mathrm{ha}^{-1}$ may indicate that further increases in 'Beauregard' yield are not possible through the manipulation of fertilizer $\mathrm{N}$ inputs. However, it is also possible that as $\mathrm{N}$ was increased, another nutrient became limiting. Leaf nutrient analysis data indicated that phosphorus $(\mathrm{P})$ and potassium $(\mathrm{K})$ increased by $44 \%$ and $55 \%$, respectively, as $\mathrm{N}$ was increased from 0 to 50 $\mathrm{kg} \cdot \mathrm{ha}^{-1}$, but no further increases were observed as $\mathrm{N}$ rate was increased (data not shown). $\mathrm{P}$ and $\mathrm{K}$ are relatively immobile in the soil and optimum root architectural development is necessary for the efficient acquisition of these and other non-mobile nutrients (Jackson et al., 2008; Lynch, 1995; Zhu and Lynch, 2004). Our results indicate that $\mathrm{N}$ deprivation can directly alter root architecture development, which in turn diminishes the plant's ability to acquire other nutrients. Follow-up studies could investigate if further increments in LR development attributes and SR yields are possible with increased $\mathrm{N}$ rates if $\mathrm{P}$ or $\mathrm{K}$ rate treatments are included. Other micro- or macronutrients should also be considered. These results underscore the importance of gaining an understanding of nutrient effects on root architecture, especially in a crop species in which LR development is fundamentally associated with yield determination (Villordon et al., 2012).

The results from the SPLIT ROOT and N PLACEMENT experiments are consistent with evidence from model systems and other crop species that localized $\mathrm{N}$ availability is critical for LR signaling development (Lima et al., 2010; Zhang and Forde, 1998; Zhang et al., 2007). In particular, there was significant variability in 1LR and 2LR development associated with the local presence or absence of $\mathrm{N}$ in the growth substrate (Figs. 6 and 7). The ability of plants to proliferate LRs preferentially in nutrient-rich patches is well documented in literature, but the signaling mechanisms are not well characterized (Zhang et al., 2007). Our results are similar to early work in barley (Hordeum vulgare) that provided evidence that localized $\mathrm{NH}_{4}^{+}$supply stimulated LR proliferation (Drew, 1975; Drew et al., 1973). Most of the previously cited studies were conducted either in solution or in a growth substrate supplied with nutrient solution rather than fertilizer granules. Our work used sand and fertilizer granules to more closely mimic natural conditions. More importantly, we have previously calibrated the timing of LR development and 
Total second order lateral root length

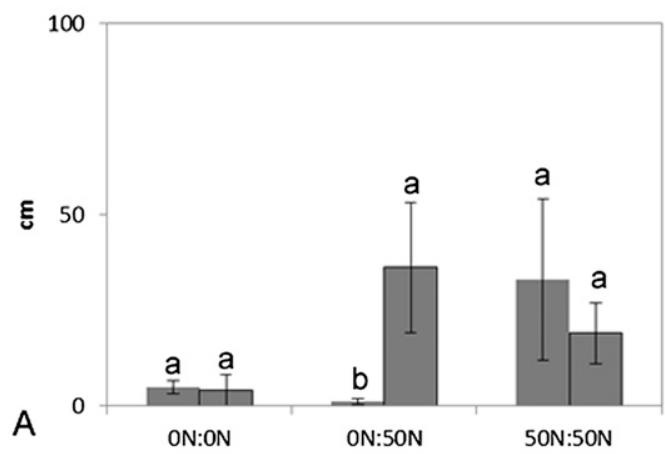

Total number of second order lateral roots

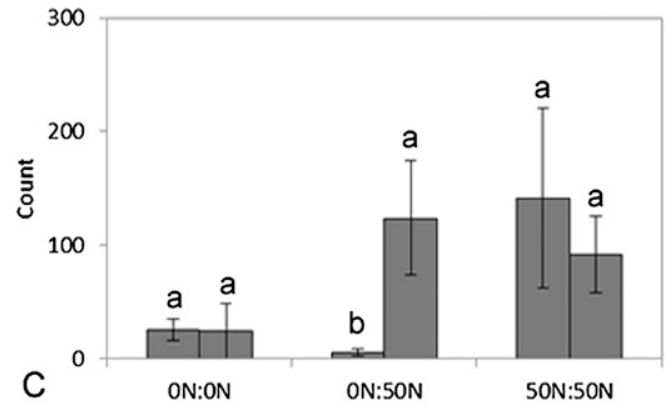

Second order lateral root length density

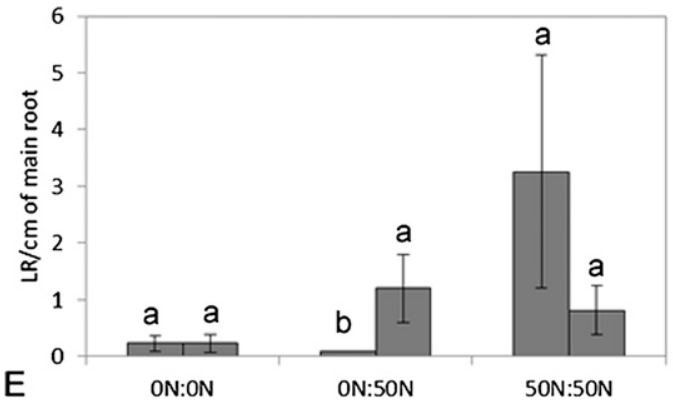

Total first order lateral root length

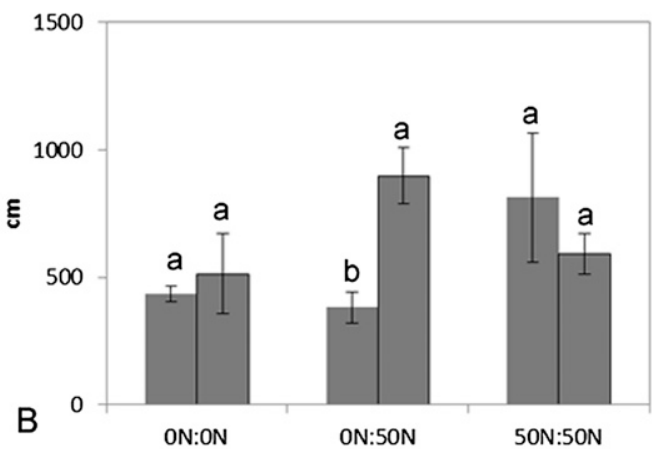

Total number of first order lateral roots

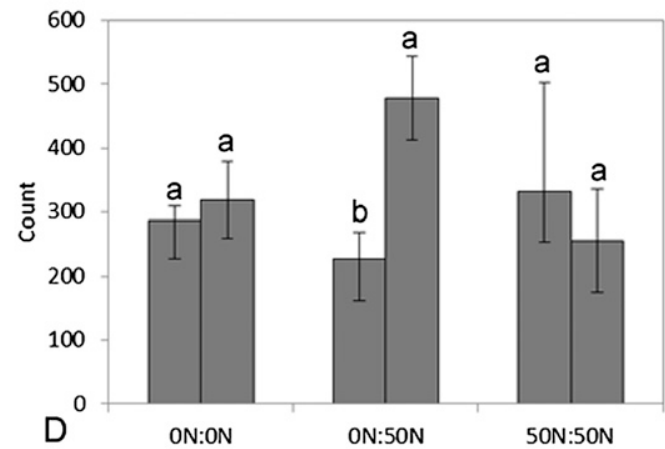

First order lateral root length density

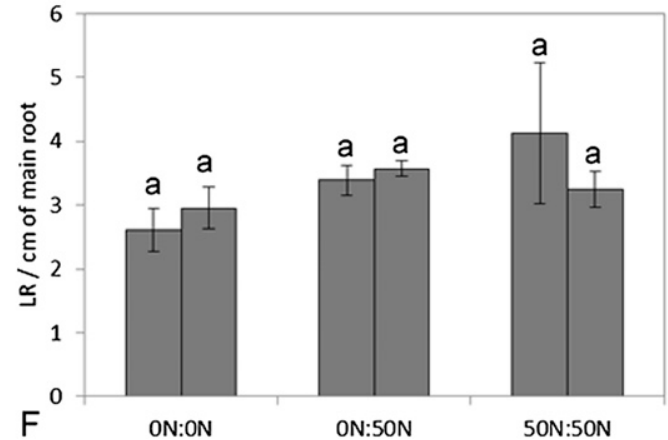

Fig. 6. Some statistical descriptive data of lateral root attributes of 'Beauregard' sweetpotato plants in split-root experiments. Paired $t$ test was performed to determine if roots in each partition varied in lateral root development attributes. $50 \mathrm{~N}=50 \mathrm{~kg} \cdot \mathrm{ha}^{-1} \mathrm{~N} ; 0 \mathrm{~N}=$ unfertilized control.

SR formation events in the greenhouse with field data (Villordon et al., 2009a, 2009b, 2011). When urea is added to the soil, it is hydrolyzed to form ammonia and carbon dioxide, and the $\mathrm{NH}_{4}^{+}$retained in the soil is subsequently oxidized to nitrite and $\mathrm{NO}_{3}{ }^{-}$ (Bremner and Krogmeier, 1989). This pattern of $\mathrm{N}$ form and availability has also been observed in our culture system as evidenced by temporal $\mathrm{NO}_{3}{ }^{-}$and $\mathrm{NH}_{4}{ }^{+}$data from a separate experiment using growth substrate with or without added urea (Table 1). At 10 and $15 \mathrm{~d}$, laboratory analyses failed to detect $\mathrm{NH}_{4}{ }^{+}$ but detected $\mathrm{NO}_{3}{ }^{-}$presence; at $20 \mathrm{~d}$, there was no detectable $\mathrm{NO}_{3}{ }^{-}$presence (Table 1). In this same experiment, we observed that LR length leveled off after $15 \mathrm{~d}$ (data not shown). The pattern of $\mathrm{NH}_{4}{ }^{+}$and $\mathrm{NO}_{3}{ }^{-}$presence and LR elongation in our study appear to be consistent with the observation by Lima et al. (2010) that local $\mathrm{NH}_{4}{ }^{+}$supply increased Arabidopsis LR initiation and branching, whereas elongation of LRs was simulated mainly by $\mathrm{NO}_{3}{ }^{-}$. Followup studies might clarify the specific roles of $\mathrm{NO}_{3}{ }^{-}$and $\mathrm{NH}_{4}{ }^{+}$forms in sweetpotato LR development. The information that local $\mathrm{N}$ variation directly influences sweetpotato LR development can be used to develop and evaluate methods that optimize $\mathrm{N}$ fertilizer placement in production systems. Based on our results, the broadcast application and incorporation of $\mathrm{N}$ before forming of ridges is the method of application that helps to ensure optimum sweetpotato root architecture development during the critical period of SR development. However, many growers apply fertilizer into the soil profile with an injection implement (Cannon, personal communication), which generally precludes uniform mixing of the fertilizer material with the soil substrate. Leaf nutrient analysis data from MIX N and BOTTOM N treatments showed that the former treatment had $86 \%$ and $60 \%$ greater $\mathrm{P}$ and $\mathrm{K}$, respectively, compared with the latter treatment (data not shown). These preliminary $\mathrm{N}$ PLACEMENT leaf nutrient data mirror the results from N RATE experiments and indicate that $\mathrm{N}$ placement can directly alter root architecture development, which in turn influences the capacity of the root system to acquire nutrients from the soil. An important limitation of our work is that we assumed that internal $\mathrm{N}$ content among cuttings had constant or negligible effects. The potential mitigating effects of variation in internal $\mathrm{N}$ content on LR development, especially early in the establishment of a cutting, cannot be ruled out and should be investigated further.

There is a paucity of evidence that links specific genes with LR developmental events, which include priming, initiation, development through the cortex, and subsequent emergence of LRs, within the context of SR formation in sweetpotato. Kim et al. (2005) have cloned and characterized a sweetpotato 
Total second order lateral root length

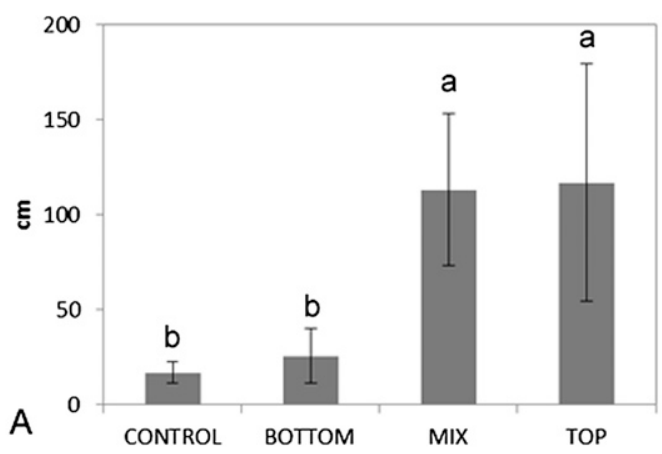

Total number of second order lateral roots

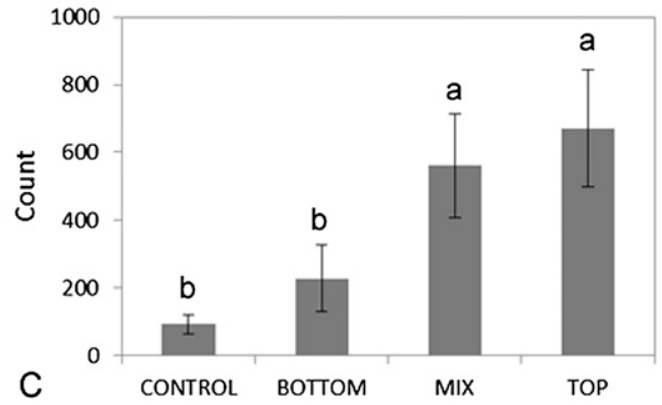

Second order lateral root density

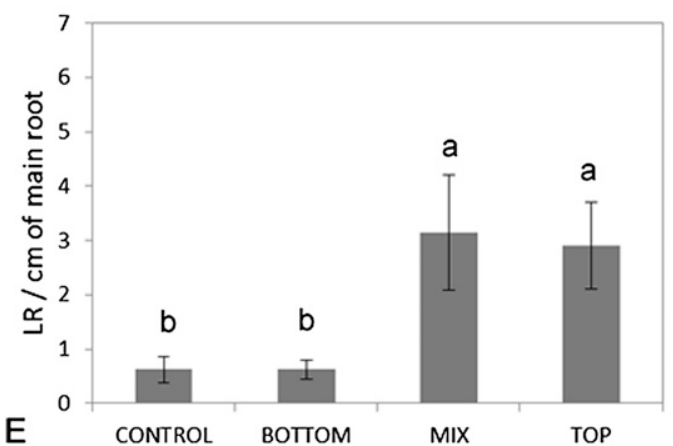

Total first order lateral root length

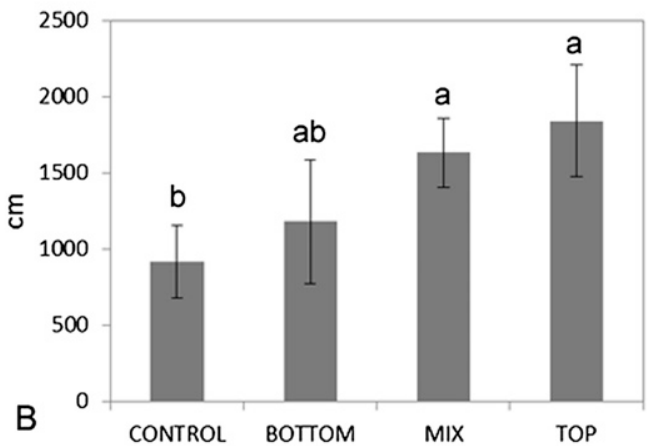

Total number of first order lateral roots

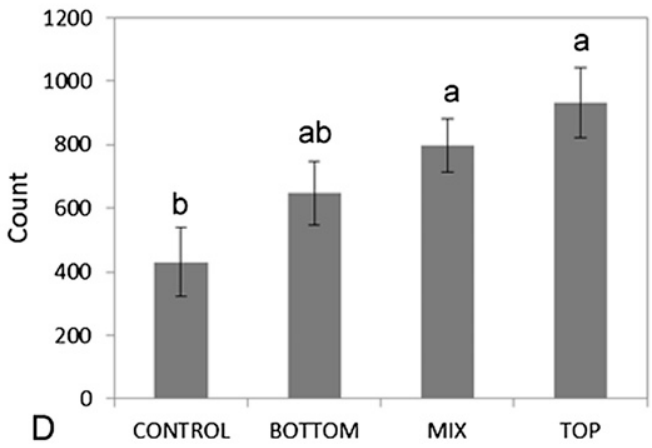

First order lateral root density

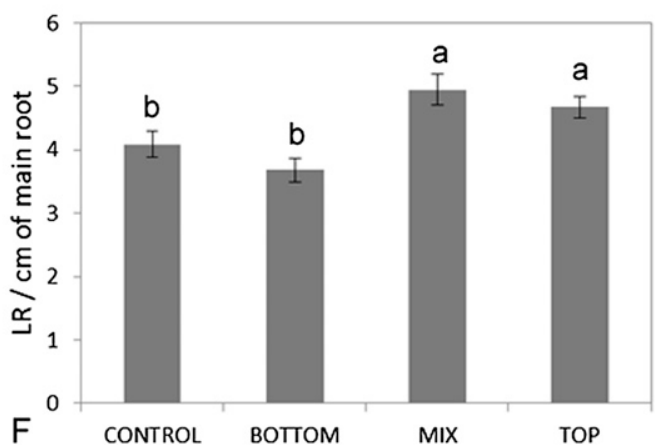

Fig. 7. Some statistical descriptive data of lateral and adventitious root attributes of 'Beauregard' sweetpotato subjected to different nitrogen (N) fertilizer placement treatments. Columns with different letters differ significantly at the $5 \%$ level by Fisher's least significant difference. $\mathrm{CONTROL}=$ no fertilizer $\mathrm{N}$ added; BOTTOM = fertilizer $\mathrm{N}$ placed $4 \mathrm{~cm}$ from the bottom of the pot; $\mathrm{MIX}=$ fertilizer $\mathrm{N}$ was pre-mixed with growth substrate; TOP = fertilizer $\mathrm{N}$ was placed $4 \mathrm{~cm}$ from the surface of the growth substrate. $\mathrm{N}$ was applied as granular urea at a rate equivalent to $50 \mathrm{~kg} \cdot \mathrm{ha}^{-1}$.

Table 1. Ammonium and nitrate presence at four time periods in growth substrate with or without the equivalent of $50 \mathrm{~kg}$ nitrogen/ha applied as urea. $^{\mathrm{z}}$

\begin{tabular}{llccccc}
\hline & & \multicolumn{4}{c}{ Day (ppm) } \\
\cline { 3 - 6 } & & 5 & 10 & 15 & 20 \\
\hline Control & $\mathrm{NH}_{4}{ }^{+}$ & 0 & 0 & 0 & 0 \\
& $\mathrm{NO}_{3}{ }^{-}$ & 0 & 0 & 0 & 0 \\
With urea & $\mathrm{NH}_{4}^{+}$ & $21.0 \pm 4$ & 0 & 0 & 0 \\
& $\mathrm{NO}_{3}{ }^{-}$ & 0 & $1.7 \pm 1$ & $1.0 \pm 1$ & 0 \\
\hline
\end{tabular}

${ }^{\mathrm{z} U r e a}$ was premixed with washed river sand containing the equivalent of $50 \mathrm{~kg}$ nitrogen/ha and $134 \mathrm{~kg} \cdot \mathrm{ha} \mathrm{a}^{-1}$ each of $\mathrm{P}_{2} \mathrm{O}_{5}$ and $\mathrm{K}_{2} \mathrm{O}$. Presence data are means \pm SEM of three replications.

MADS-box gene (IbAGL17) isolated from SRs that belong to the same family as ANR1, the main function of which is related to the development of $\mathrm{LR}$ in response to $\mathrm{NO}_{3}{ }^{-}$ availability within the soil (Zhang and Forde,
1998). Another MADS-box gene, IbMADS1, has been documented as related to SR initiation in sweetpotato and transcripts were localized to emerging LR primordia and immature meristematic cells such as the protoxylem and protophloem within the AR stele (Ku et al., 2008). However, there is no evidence that indicates that IbMADS1 is responsive to nutritional cues. It has been shown in Arabidopsis that LRs are derived from pericycle founder cells positioned adjacent to the two protoxylem poles (Blakely et al., 1982). The most common criterion used to define the onset of LR formation is the first periclinal division of these founder cells (Esau, 1977; Lloret al., 1989). The growth of the LR initial through the cortex and subsequent emergence involve tissue rearrangement. It is of interest that EXP14, an expansin-like gene that mediates cell-wall loosening, is involved in promoting LR emergence in Arabidopsis (Lee et al., 2013). An expansin precursor has previously been identified in sweetpotato and it has been suggested that it is involved in the initiation of SR development (You et al., 2003). However, a follow-up study of one of the genes revealed that down-regulation of the IbEXP1 expansin gene resulted in enhanced SR development (Noh et al., 2012).

Our work corroborates previous evidence that at least one SR-specific gene belonging in the same class as ANR1, an N-responsive gene, mediates the development of LRs. This provides a critical link between SR formationrelated gene expression and environmental conditions (nutritional cue). Our work underscores the need, as earlier suggested by Kays (1985), for additional research on the effect of altering agronomic and agroclimatic variables 
on the sweetpotato root system. Pardales and Yamauchi (2003) first suggested that sweetpotato root architecture can be manipulated not only for agronomic production, but also for crop improvement. Villagarcia et al. (1998) documented genotypic responses in $\mathrm{N}$ use efficiency among two sweetpotato genotypes subjected to limited supplies of $\mathrm{N}$. Although the latter work did not specifically include root architecture information, the data suggest that it is possible to select for sweetpotato genotypes with reduced $\mathrm{N}$ requirement, especially under N-deficient conditions. However, the incorporation of root architecture information into routine breeding is subject to practical difficulties resulting from the complex nature of the soil environment and the difficulty of incorporating screening of root architecture attributes in field conditions (De Dorlodot et al., 2007). Clearly, further work is needed to determine the feasibility of incorporating root architecture attributes in ongoing sweetpotato breeding work.

\section{Conclusion}

Our current understanding of the regulation of root architecture is based on a subset of well-characterized "model" species including major global food crops such as wheat, rice, and maize. We have generated evidence that variation in $\mathrm{N}$ rate and local availability profoundly influence root architecture development at the critical SR formation period in sweetpotato, a root crop of global importance. Our results helped to explain the lack responses over a range of $\mathrm{N}$ rates in 'Beauregard' and other cultivars in field trials. The findings from experiments designed to mimic local $\mathrm{N}$ variability corroborate experimental results from model species that the presence of $\mathrm{N}$ is critical to LR signaling and development. This information can be used to further optimize management and environmental variables during the critical SR initiation period to further optimize SR yield in sweetpotato.

\section{Literature Cited}

Alvarez, J.M., E.A. Vidal, and R.A. Gutierrez. 2012. Integration of local and systemic signaling pathways for plant $\mathrm{N}$ responses. Curr. Opin. Plant Biol. 15:185-191.

Blakely, L.M., M. Durham, T.A. Evans, and R.M. Blakely. 1982. Experimental studies on lateral root formation in radish seedling roots. I. General methods, developmental stages, and spontaneous formation of laterals. Bot. Gaz. 143:341-352.

Bremner, J.M. and M.J. Krogmeier. 1989. Evidence that the adverse effect of urea fertilizer on seed germination in soil is due to ammonia formed through hydrolysis of urea by soil urease. Proc. Natl. Acad. Sci. USA 86:8185-8188.

Casimiro, I., T. Beeckman, N. Graham, R. Bhalerao, H. Zhang, P. Casero, G. Sandberg, and M. Bennett. 2003. Dissecting Arabidopsis lateral root development. Trends Plant Sci. 8:165-171.

De Dorlodot, S., B. Forster, L. Pages, A. Price, R. Tuberosa, and X. Draye. 2007. Root system architecture: Opportunities and constraints for genetic improvement of crops. Trends Plant Sci. 12:474-481.

De Smet, I., L. Signora, T. Beeckman, D. Inze, C Foyer, and H. Zhang. 2003. An abscisic acidsensitive checkpoint in lateral root development of Arabidopsis. Plant J. 33:543-555.

Drew, M.C. 1975. Comparison of the effects of a localized supply of phosphate, nitrate, ammonium and potassium on the growth of the seminal root system, and the shoot, in barley. New Phytol. 75:479-490.

Drew, M.C., L.R. Saker, and T.W. Ashley. 1973. Nutrient supply and the growth of the seminal root system in barley. I. The effect of nitrate concentrations on the growth of axes and laterals. J. Expt. Bot. 24:1189-1202.

Dubrovsky, J.G. and B.G. Forde. 2012. Quantitative analysis of lateral root development: Pitfalls and how to avoid them. Plant Cell 24:4-14.

Esau, K. 1977. Anatomy of seed plants. John Wiley and Sons, New York, NY.

Guertal, E.A. and J.A. Kemble. 1997. Nitrogen rate and within-row plant spacing effects on sweetpotato yield and grade. J. Plant Nutr. 20:355-360.

Hill, W.A., D.G. Mortley, and S.M. Crossman. 1988. Fertilizer N dependent and independent sweetpotato cultivars, p. 703-713. In: Degras, L.M. (ed.) Proc. 7th Symp. Intl. Tropical Root Crops, Guadelupe, French West Indies, 1-6 July 1985. INRA Publ., Versailles, Cedex, France.

Ivanchenko, M., G. Muday, and J. Dubrovsky. 2008. Ethylene-auxin interactions regulate lateral root initiation and emergence in Arabidopsis thaliana. Plant J. 55:335-347.

Jackson, L.E., M. Burger, and T.R. Cavagnaro. 2008. Roots, nitrogen, transformations, and ecosystem services. Annu. Rev. Plant Biol. 59:341363.

Johnson, J.F., C.P. Vance, and D.L. Allan. 1996 Phosphorus deficiency in Lupinus albus. Altered lateral root development and enhanced expression of phosphoenolpyruvate carboxylase. Plant Physiol. 112:657-665.

Kays, S.J. 1985. The physiology of yield in the sweetpotato, p. 79-132. In: Bouwkamp, J. (ed.) Sweetpotato products: A natural resource for the tropics. CRC Press, Boca Raton, FL.

Kim, S.H., T. Hamada, M. Otani, and T. Shimada 2005. Cloning and characterization of sweetpotato MADS-box gene (IbAGL17) isolated from tuberous root. Plant Biotechnol. 22:217220

Ku, A.T., Y. Huang, Y. Wang, D. Ma, and K. Yeh 2008. IbMADS1 (Ipomoea batatas MADS-box 1 gene) is involved in tuberous root initiation in sweet potato (Ipomoea batatas). Ann. Bot. (Lond.) 102:57-67.

Kutz, A., A. Muller, P. Henning, W.M. Kaiser, M. Piotrowsky, and E.W. Weiler. 2002. A role for nitrilase 3 in the regulation of root morphology in sulphur-starving Arabidopsis thaliana. Plant J. 30:95-106.

Lee, H.W., M.J. Kim, N.Y. Kim, S.H. Lee, and J. Kim. 2013. LBD18 acts as an transcriptional activator that directly binds to the EXPANSIN14 promoter in promoting lateral root emergence of Arabidopsis. Plant J. 73:212-224.

Lima, J.E., S. Kojima, H. Takahashi, and N. von Wiren. 2010. Ammonium triggers lateral root branching in Arabidopsis in an ammonium transporter 1:3-dependent manner. Plant Cell 22:3621-3633.

Lloret, P.G., P.J. Casero, A. Pulgarín, and J. Navascués. 1989. The behavior of two cell populations in the pericycle of Allium cepa, Pisum sativum and Daucus carota during early lateral root development. Ann. Bot. (Lond.) 63:465-475.

Lopez-Bucio, J., E. Hernandez-Abreu, L. SanchezCalderon, M.F. Nieto-Jacobo, J. Simpson, and L. Herrera-Estrella. 2002. Phosphate availability alters architecture and causes changes in hormone sensitivity in the Arabidopsis root system. Plant Physiol. 129:244-256.

Lynch, J. 1995. Root architecture and plant productivity. Plant Physiol. 109:7-13.

Mulkey, W.A., W.B. McLemore, III, and T.P. Talbot. 1994. Nitrogen fertilization of sweetpotato and its effect on root set and yield. HortScience 29:726.

Noh, S.A., H.S. Lee, Y.S. Kim, K.H. Paek, J.S Shin, and J.M. Bae. 2012. Down-regulation of the IbEXP1 gene enhanced storage root development in sweetpotato. J. Expt. Bot. 64:129-142.

Pardales, J.R. and A. Yamauchi. 2003. Regulation of root development in sweetpotato and cassava by soil moisture during their establishment period. Plant Soil 255:201-208.

Phillips, S.B., J.G. Warren, and G.L. Mullins. 2005. Nitrogen rate and application timing affect Beauregard sweetpotato yield and quality. HortScience 40:214-217.

Schultheis, J.R., W.R. Jester, and C.W. Averre. 1995. The influence of nitrogen rate and timing on Beauregard sweetpotato yield and quality. HortScience 30:758.

Togari, Y. 1950. A study of tuberous root formation in sweet potato. Bul. Nat. Agr. Expt. Sta. Tokyo 68:1-96.

Villagarcia, M.R., W.W. Collins, and C.D. Raper, Jr. 1998. Nitrogen uptake and nitrogen use efficiency of two sweetpotato genotypes during early stages of storage root formation. J. Amer. Soc. Hort. Sci. 123:814-820.

Villordon, A., D.R. LaBonte, and N. Firon. 2009a. Development of a simple thermal time method for describing the onset of morpho-anatomical features related to sweetpotato storage root formation. Sci. Hort. 121:374-377.

Villordon, A.Q., D.R. LaBonte, N. Firon, Y. Kfir, E. Pressman, and A. Schwartz. 2009b. Characterization of adventitious root development in sweetpotato. HortScience 44:651-655.

Villordon, A., D. LaBonte, and J. Solis. 2011. Using a scanner-based minirhizotron system to characterize sweetpotato adventitious root development during the initial storage root bulking stage. HortScience 46:513-517.

Villordon, A., D. LaBonte, J. Solis, and N. Firon. 2012. Characterization of lateral root development at the onset of storage root initiation in Beauregard sweetpotato adventitious roots. HortScience 47:961-968.

Wilson, L.A. and S.B. Lowe. 1973. The anatomy of the root system in West Indian sweet potato [Ipomoea batatas (L.) Lam.] cultivars. Ann. Bot. (Lond.) 37:633-643.

You, M.K., C.G. Hur, Y.S. Ahn, M.C. Suh, B.C. Jeong, J.S. Shin, and J.M. Bae. 2003. Identification of genes possibly related to storage root induction in sweetpotato. FEBS Lett. 536:101-105.

Zhang, H. and B. Forde. 1998. An Arabidopsis MADS box gene that controls nutrient-induced changes in root architecture. Science 279:407409 .

Zhang, H., H. Rong, and D. Pilbeam. 2007. Signalling mechanisms underlying the morphological responses of the root system to nitrogen in Arabidopsis. J. Expt. Bot. 58:2329-2338.

Zhu, J. and J.P. Lynch. 2004. The contribution of lateral rooting to phosphorus acquisition efficiency in maize (Zea mays) seedlings. Funct. Plant Biol. 31:949-958. 